\title{
NIH Center for Scientific Review
}

National Cancer Institute

\section{Source}

National Cancer Institute. NIH Center for Scientific Review. NCI Thesaurus. Code C19764.

Provides staff support to the Office of the Director, $\mathrm{NIH}$, in the formulation of grant application review policies and procedures. In addition, CSR provides central receipt of all PHS applications for research and review. 